\title{
Review of Mary Bosworth and Carolyn Hoyle, What is Criminology?
}

\section{Oxford, UK: Oxford University Press, 2011. ISBN: 9780199571826, 0199571821 , US\$150 (hard-cover), US\$50 (paperback)}

\author{
Alistair Fraser \\ Received: 15 May 2012 / Accepted: 28 May 2012 / Published online: 29 June 2012 \\ (C) The Author(s) 2012. This article is published with open access at Springerlink.com
}

\section{Review}

What is criminology? The short answer, to paraphrase the British playwright Alan Bennett, is 'just one bloody crime after another.' The long answer is to be found between the pages of Bosworth and Hoyle's wide-ranging new collection, in which leading criminologists reflect on the current status of their discipline. The volume arrives in the midst of a 'reflexive turn' (Bourdieu and Wacquant 1992) in the social sciences generally, and recent debates regarding the role and function of criminology in public life (Loader and Sparks 2010; Wacquant 2011). Consisting of 35 chapters over 550 hard-bound pages, the collection represents a weighty contribution to both debate and bookshelf.

Contributions come from some of the leading criminological thinkers in the UK, US, Canada, Europe, Australia and South Africa. Their charge was to consider the purpose, impact, methods and import of criminology, past and present. Unsurprisingly, for a selfconsciously 'eclectic discipline', the results are both varied in content and broad in scope. Contributions are loosely grouped into two 'parts'- 'Criminology and Its Constituents' and 'Criminology and Its Borders' - each containing subsets of guiding questions (p.7):

1. What is Criminology For?

2. What is the Impact of Criminology?

3. How Should Criminology be Done?

4. What are the Key Issues and Debates in Criminology Today?

5. What Challenges does the Discipline of Criminology Currently Face?

6. How has Criminology as a Discipline Changed over the Last Few Decades?

This device works well to marshal a somewhat unruly and disparate set of contributions; as a result, though the volume can be productively dipped in and out of, it also functions as a chronological whole. And as a whole, it is wide-ranging and thought-provoking, with chapters

\footnotetext{
A. Fraser $(\bowtie)$

Department of Sociology, University of Hong Kong, Room 1215, K.K. Leung Building, Pokfulam Road, Hong Kong 999077, China

e-mail: afraser@hku.hk
} 
high on personal reflection and low on unnecessary decoration. Contributions are generally short, to the point, and easily digested, with some richly rewarding insights.

Given the depth, weight and scope of the volume itself (many of the chapters could easily stimulate 1,500 words in and of themselves), this review is necessarily brief and selective. Suffice to say that there are contributions from a great many 'heavyweight' criminologists, and anyone interested in learning from, and reflecting on, their answers to the question 'What is Criminology?' should dive right in. What I propose to do in the remainder is to examine more closely the implications and relevance of the collection for Asian criminology.

The first unavoidable observation is the lack of contributions from Asia. Of the 45 contributors, not one is based at an Asian institution, or draws on research from an Asian context (although the Asian Journal of Criminology is mentioned on page 1!). What the contributions lack in reach, however, they make amends for in ambition. The foreword, by John Braithwaite, laments the fact that criminology has "too weak a comparative imagination, though the rise of higher quality crime research in Asia and at Europe's margins feeds hope" (Braithwaite, p.viii); a theme picked up a few pages later in the editor's introduction, as Hoyle and Bosworth delineate the current 'world map' of criminology. Like the classical Mercator world map, which has been shown to present certain countries as smaller than they are in reality, the 'world map' of criminological knowledge is overwhelmingly skewed away from countries in Asia and the global south (Cain 2000; Sheptycki 2008). Nonetheless, some of the contributions in the collection can assist the growth of knowledge in the global 'periphery' and perhaps bring it centre stage in the context of the shifting sands of global power. It is these chapters I propose to draw out.

The chapter by Shearing and Marks, on South African criminology (particularly ethnography), highlights the complex intersections of power-knowledge in a post-colonial context, and the necessity for careful and sensitive unpacking of persistent inequalities. Casting South Africa as a 'Disney World' for criminology - a playground for the rich, and battleground for the poor - the chapter takes the reader on a 'tour' of recent ethnographic studies, which deal frontally with the historical and cultural landscape of South Africa, particularly the intellectual legacy of colonialism: 'West knows best'. In excavating a criminology that is grounded fundamentally in sensitive and evocative ethnography, Shearing and Marks argue that:

The colonial, and an even wider eurocentric/western, legacy has to be accounted for in "doing" criminology in South Africa since it impacts on forms of crime and deviance, meanings attributed to crime and social control, and the variety of governance arrangements that existed in a fractured society (p. 126).

A later chapter, by Chris Cunneen, develops this conceptual approach from an Australian, post-colonial perspective. Drawing from postcolonial theory in law, politics and sociology (particularly the work of Said and Spivak), Cunneen laments the lack of attention to the ongoing structural, cultural and psychosocial legacies of colonialism, and the resistances and adaptations engendered. For Cunneen, following the Foucauldian critique of criminology, "The dominant intellectual frameworks of criminology were established in the west with a view of understanding and exploring the phenomena of crime and crime control within specific western contexts" (p.251). Concluding with a call to engage with issues of diaspora, unequal treatment, state crime and human rights through the diverse writings of Biko Agozino, Frantz Fanon, Stuart Hall and Paul Gilroy, Cunneen argues for a "critical and reflexive framework that questions the centrality of a Western understanding of crime and control" (p.252). 
Ben Bowling's chapter, on transnational policing, is rooted in a similarly expansive and discursive criminological imagination. Drawing on Maureen Cain's resonant questions regarding the applicability of western criminological concepts to other cultural contexts, Bowling powerfully employs the concept of 'iatrogenesis'-a clinical term denoting unintended harm, or side effects - to demonstrate the social injuries that unreflective export of criminal justice may cause. For Bowling, building a criminology that evades criticisms of relativism, ethnocentrism, Occidentalism or Orientalism requires the bringing together of "transnational and comparative research from all regions of the world to build a globally inclusive and cosmopolitan discipline...to explore problems that do not belong exclusively in one place or another and can therefore be understood by analysing linkages between places" (p.363). This, Bowling argues, is the aspiration and promise of a truly 'global' criminology.

The chapter by Katja Franko Aas, 'Visions of Global Control', similarly stakes out a claim for, and path towards, a criminology explicitly geared towards the global question. Decentering the criminological world-map by asking "not only... what is criminology, but also where and who is criminology?" (p.407), Aas sets out a developed theoretical and methodological agenda for a 'criminology of the periphery'. Unlike those who purport to a 'global' agenda, but fail to confront the deeply uncomfortable convergences of geo-political and intellectual power in the construction of contemporary criminological knowledge, Aas draws from the work of Bourdieu and Calhoun in analysing the 'misrecognition' of cosmopolitanism amongst scholars. For Aas, the project of a global criminology is to recognise, analyse, and learn from the divisions and frictions of late modernity; capturing forms of domination wherever they exist. Chapters by Rafter, Parmentier and Nelken also deal in different ways with comparative and transnational issues, with Nelken dealing sensitively with the question of power and learning. In relation to comparative research, he quotes T S Eliot: "the end of our exploring. Will be to arrive where we started, And know the place for the first time" (p.394). The fragile truth of this statement should be heeded in the development of transnational imaginaries.

Other stand-out chapters for me were Jeff Ferrell's playfully subversive re-reading of Sykes and Matza's 'techniques of neutralisation', Pat Carlen's fearsome demolition of evangelism and faddism in criminology, and David Garland's plea for criminology to remained anchored to the 'fundamental disciplines'. In Ferrell's chapter, the delinquent is recast as a Bourdieusian critical sociologist, able to see through the hypocrisies and twisted moralities of the dominant social order; with Ferrell gently nudging criminologists towards 'becoming deviant' themselves, reimagining taken-for-granted ideas into a fleeting bricolage fit for the twenty-first century. Carlen's chapter sets its sights on so-called 'brand-name' criminologies - specifically public, cultural and critical criminologies - arguing that unreflective use of such prefixes may produce a labelling effect that is against the principles of 'open and ongoing enquiry' that lie at the heart of the criminological endeavour: namely "to think the unthinkable" (p.107). While being public, cultural and critical is crucial to good criminology, these are means and not ends - criminologists should be "artisans not partisans" (p.106). Garland's tone is similarly cautionary in his discussion of the increasing institutional autonomy of criminology as a discipline. Garland intuits a threat to criminology's theoretical base in the 'fundamental disciplines' in these developments, as research agendas become more autopoeitic and less laterally-minded. In a similar vein, Lucia Zedner mounts a forceful critique of criminology's willful blindness towards legal debate and discourse relating to criminalisation.

In any undertaking of this breadth and magnitude, as the editors themselves admit, there will be claims of unrepresentativeness, of gaps, and of omissions. In the introduction, the 
editors seek to ward off at least some such criticisms in setting out their criteria ('second generation' criminologists), and explaining that a number contributors declined the invitation. While these self-criticisms are well taken, there are a few points I would like to add. First, interestingly for a self-conscious discipline, many of the contributors explicitly place themselves in but not of criminology - to adopt an ethnographic metaphor, as 'observer-asparticipant' or 'participant-as-observer'. Overall, however, I felt that the collection may have been broadened by making invitations beyond criminology (to 'complete observers'), specifically to sociologists, anthropologists or social theorists who could act as critical friends. Second, partly as a result of its nature - as a collection of established and respected thinkers reflecting on their craft-it feels rather more backward looking than forward looking. In 'mapping the boundaries' of criminology, a path forward may have been more forthcoming. This could have come, for example, from some involvement from the 'third' (or even 'fourth') generation of criminologists (they do admit to an 'absence of younger scholars'); or from discussion of the future of criminological curricula, postgraduate funding opportunities, alterations in pedagogy and ethical review boards, and the coming research landscape.

As an exercise in reflection and reflexivity, however, the collection is an undoubted success - and will, I am certain, stimulate further debate and reflection in moving towards a range of criminological futures. In Asia, it may be hoped that some of the key messages from the collection are taken up and developed so that Asian criminology might be part of that future.

Open Access This article is distributed under the terms of the Creative Commons Attribution License which permits any use, distribution, and reproduction in any medium, provided the original author(s) and the source are credited.

\section{References}

Bourdieu, P., \& Wacquant, L. (1992). An invitation to reflexive sociology. Chicago: University of Chicago Press. Cain, M. (2000). Orientalism, Occidentalism and the sociology of crime. British Journal of Criminology, 40(2), 239-260.

Loader, I., \& Sparks, R. (2010). Public criminology? London: Routledge.

Sheptycki, J. (2008). Transnationalism, Orientalism and crime. Asian Journal of Criminology, 3(1), 13-35.

Wacquant, L. (2011). From "Public Criminology" to the reflexive sociology of criminological production and consumption: A review of public criminology. British Journal of Criminology, 51(2), 438-448. 